\title{
Comparing cities: a Barcelona Model?
}

\author{
JAMES AMELANG* \\ Departmento de Historia Moderna, Facultad de Filosofía y Letras, Universidad \\ Autónoma de Madrid, Spain
}

\begin{abstract}
Despite widespread interest in the 'Barcelona Model' of urban planning and architecture as of late, little is known about the city's historical development. This article suggests as a remedy more concerted efforts in comparative history. Comparison with other cities reveals three anomalies: the condition of ex-capitality; a distinctive focus on civil society as the leading dynamic in the city's evolution; and a self-image as a classic 'second city', that is, an economic as opposed to political centre. The essay closes with suggestions for future research, and stresses the need for a specifically cultural approach to the urban past.
\end{abstract}

That Barcelona is at long last an 'international' city, endowed with an impressive image as a dynamic and creative urban centre, can hardly be questioned. Yet despite the widespread interest it has aroused, relatively little is actually known about Barcelona's history. This is especially true of the availability of publications in English, which are few and far between. The following brief observations can hardly close the gap. However, they do trace a few lines of research and reflection that may serve as a preliminary basis for a broad and explicitly comparative analysis of the city's past.

\section{Points of comparison}

There are many ways of structuring comparisons between cities. Urban historians have favoured two in particular. The first involves a thematic approach, in which one examines a single issue or series of issues in relation

\footnotetext{
* This article has two points of departure. The first was a year-long symposium devoted to a critical examination of Catalan historiography (2002-03) sponsored by the Centre de Cultura Contemporània in Barcelona, and organized by Josep M. Fradera. My contribution was published as 'Peculiaritats barcelonines', in J.M. Fradera and E. Ucelay-Da Cal (eds.), Notícia nova de Catalunya (Barcelona, 2005), 39-62. The other was a paper presented to a Davis Centre seminar at Princeton University in February 2005. In both cases I am indebted to fellow participants for their suggestions and comments. I am also grateful to Ed Baker, Martin Baumeister, Xavier Gil, Mauro Hernández, Stephen Jacobson, Lou Rose and especially Josep M. Fradera for reading and remarking on earlier drafts of this essay. They are not, however, to be held to account for any of the opinions expressed therein.
} 
to more than one urban area. ${ }^{1}$ The other focuses not on a particular theme or question, but on the cities themselves. The aim therein is to identify similarities and divergences in individual urban trajectories by directly contrasting one city with another. ${ }^{2}$ I would like briefly to experiment with combining both approaches. That is, I will try to isolate several singularities in Barcelona's past, and then bring them into clearer focus by looking at how they fit into the historical patterns of cities elsewhere. My aim in so doing is not to devise an abstract 'urban model', as has been recently proposed. ${ }^{3}$ Rather, I will hastily evoke some specific urban experiences that present suggestive resemblances to - and equally suggestive departures from - the historical evolution of Barcelona. The overall aim of comparison is not to pile up facts. Rather, its purpose, as its defender Marc Bloch pointed out, is 'to open up new avenues of research' by 'filling in certain gaps in documentation by means of hypotheses based on analogy'. Discovering the pertinence (and limits) of concrete analogies allows the historian to differentiate between what is particular, and even unique, to his or her city, and what most cities share in common. While it is a rudimentary task, it is also a helpful guide when trying to distinguish one tree in the forest from another.

I should also point out that in practical terms, comparison means not only looking widely, but also closely. For example, a quick glance might suggest that civic government in late medieval and early modern Barcelona underwent the same sort of oligarchization that took place throughout western Europe during these centuries. Nevertheless, a less hurried look both at Barcelona and cities elsewhere suggests something rather different: that while Barcelona, like other cities, did see an increase in oligarchical control over higher municipal offices, it also, unlike other cities, maintained and even expanded the formal participation of guild masters in civic

${ }^{1}$ One example would be recent attempts to compare urban planning in different capital cities, as in Michael Wagenaar's 'Monumental centre, picturesque environs: contrasting townscapes and divergent land use in six European capitals, 1850-1914', in C. Vandermotten (ed.), Planification et stratégies de développement dans les capitales européenes (Brussels, 1994), 29-48, or Thomas Hall's Planning Europe's Capital Cities: Aspects of Nineteenth-Century Urban Development (London, 1997), which compares planning projects in fourteen such cities. Another, and more directly inspired by the methods of historical sociology, applies the same survey questions to a wide range of cities, as in M. Gribaudi (ed.), Espaces, temporalités, stratifications: exercises sur les réseaux sociaux (Paris, 1998). In either case, the comparison focuses more on the subject under study as seen in different contexts than between the cities themselves.

2 There are, to be sure, many other ways of ordering urban comparisons. For an illuminating exercise in comparing London both to an 'ideal-type' of city-state, and to different stages in its own past, see D. Keene, 'Metropolitan comparisons: London as a city-state', Historical Research, 77 (2004), 459-80.

${ }^{3}$ As in P. Rossi (ed.), Modelli di città: strutture e funzioni politiche (Turin, 1988); see also the reactions to this approach by Cristina La Rocca and Franco Angiolini in Quaderni Storici, 75 (1990), 955-64.

${ }^{4}$ M. Bloch, 'A contribution towards a comparative history of European societies', in his Land and Work in Medieval Europe: Selected Papers, trans. J.E. Anderson (New York, 1969; orig. edn 1928), 47. 
administration. ${ }^{5}$ In other words, the rise of oligarchy was accompanied by greater popular representation in local government - an unusual paradox, little found elsewhere, and of considerable interest for understanding the city's past.

A first and obvious set of comparisons takes as its focus the condition of ex-capitality. Barcelona was merely one of several capital cities that had abandoned, willingly or not, this all-important function. Yet the precise nature of its relation to this function involves some intriguing twists and turns, which comparison brings under a brighter light.

One hesitates to apply the notion of 'capital city' to the early modern and above all medieval eras. The term itself appears late in the historical lexicon, and it begins to be used regularly only in the eighteenth century. ${ }^{6}$ Even specifically designated capital cities, such as Turin after 1560, or Madrid after 1561, were rarely labelled as such. It was much more common to refer to them as court cities, or just courts, even when it was clear that the itinerant royal residences of the past had given way to sedentary, permanent centres of state bureaucracy. Most European capital cities did not, in fact, have dated birth certificates. Rather, they acquired this status gradually and unofficially, thanks largely to the long-term and finally continuous presence of their monarchs. It thus comes as no surprise to find much confusion engulfing this category.

One can start to sort out this mess by untangling some of the different criteria used to define capitals in both past and present. Perhaps the most

${ }^{5}$ See my Honored Citizens of Barcelona: Patrician Culture and Class Relations, 1490-1714 (Princeton, 1986), especially 219-21, and The Flight of Icarus: Artisan Autobiography in Early Modern Europe (Stanford, 1998), 196-201. More detailed discussion can be found in L.R. Corteguera, For the Common Good: Popular Politics in Barcelona, 1580-1640 (Ithaca, 2002). For a broad comparison of municipal politics in early modern Spain, see J.I. Fortea Pérez, 'Corona de Castilla-Corona de Aragón. Convergencias y divergencias de dos modelos de organización municipal en los siglos XVI y XVII', Mélanges de la Casa de Velázquez, n.s., 34 (2004), 17-57.

${ }^{6}$ Surprisingly little of an analytical nature has been written about pre-modern capital cities. The two main studies are both collective works: C. Da Seta (ed.), Le città capitali (Rome and Bari, 1985); and P. Clark and B. Lepetit (eds.), Capital Cities and their Hinterlands in Early Modern Europe (Aldershot, 1996). The pioneering introductory piece by the late Marino Berengo on pp. 3-15 of the former now figures, along with many other observations of interest, in his encyclopaedic L'Europa delle città: il volto della società urbana europea tra Medioevo ed Età moderna (Turin, 1999). Also of special relevance is David Ringrose's work on the economic aspects of capitality. See, for example, his 'Capital cities and their hinterlands: Europe and the colonial dimension', in Clark and Lepetit (eds.), Capital Cities, 217-40, and 'Capital cities, urbanization, and modernization in early modern Europe', Journal of Urban History, 24 (1998), 155-83.

Even less is available on ex-capitals, although see two suggestive essays: X. Gil Pujol, ‘Una cultura cortesana provincial: patria, comunicación y lenguaje en la Monarquía hispánica de los Austrias', in P. Fernández Albaladejo (ed.), Monarquía, imperio y pueblos en la España moderna (Alicante, 1997), 225-57, especially 233, and F. Bouza Alvarez, 'Sola Lisboa, casi viuda. La ciudad y la mudanza de la corte en el Portugal de los Felipes', now in his Imagen y propaganda: capitulos de historia cultural del reinado de Felipe II (Madrid, 1998), 95-120. For a preliminary introduction to this aspect of Barcelona's history, see Enric Ucelay-Da Cal's Llegar a capital: rango urbano, rivalidades interurbanas y la imaginación nacionalista en la España del siglo XX (Barcelona, 2002). 
important distinction to be made is between formal and informal capitals, that is, capitals that were recognized juridically and institutionally as such, and cities that were seen as capitals for other reasons. In regard to the latter, economic functions and status within urban networks appear to have had the greatest weight. Informal capitals were cities that occupied the core position within broad urban systems, and the highest rank within extralocal hierarchies of place. This was invariably due to their hosting multiple centralizing functions and services, ranging from administrative and other governmental activities and offices, to the concentration of elite residence and cultural institutions. Yet such functions and services represented only one side - albeit an essential one - of informal capitality. Capital cities needed also to be recognized as such. They thus required an image as capitals, in terms not only of their visibility in this guise to outsiders, but also of the self-understanding of insiders, that is, their own citizens.

There can be no question as to Barcelona's long-term role as caput regni or, to use the eloquent local expression, cap $i$ casal (literally, 'head and hearth') of the principality of Catalonia. It is especially important to keep this in mind when one considers the city's drift away from, and not toward, formal capitality. For virtually all of its history Barcelona has been the informal capital of its immediate surrounding territory, Catalonia. ${ }^{7}$ Yet during the later Middle Ages it had been a formal capital as well. The most frequent locus of residence of the itinerant kings of the farflung and multilingual confederation known as the Crown of Aragon, late medieval Barcelona was not only a court city. It was at the same time the administrative centre of Catalonia, housing the royal Chancery, the Diputació or permanent commission of the Parliamentary Estates, the central law courts and the like. This duality, of capital and court, would explain why, for example, D. Rafael d'Amat i de Cortada, the baron of Maldà, opened his late eighteenth-century description of the city by referring to Barcelona as the 'capital of the Principality of Catalonia [and] court of its counts and [the] kings of Aragon until 1410'.

The physical absence of the monarch which began intermittently in the early fifteenth century with Alfons el Magnànim (ruled 1416-58), and became permanent after the reign of Ferdinand the Catholic (14791516), nevertheless meant an undeniable demotion in status. The loss of royal residence found institutional confirmation in the appointment by Charles V of a viceroy beginning in 1521. From that point onward it would be correct in formal terms to speak of Barcelona as a viceregal capital, subordinated in a political ranking of cities to the central capital

7 There is in fact a problem of scale here with important implications for civic historiography. Barcelona has lived out all of its existence as the largest city within a relatively small and, until the nineteenth century, sparsely populated territory. Its specific history as a city has thus been absorbed by its national (Catalan) history to an extent unthinkable in, say, the relation of London to England, or Paris to France.

8 See his Viles i ciutats de Catalunya, ed. M. Aritzeta (Barcelona, 1994), 81. 
of the monarchy in Madrid (after 1561). Informally, of course, Barcelona continued to recognize itself as a capital, in terms of its central functions in Catalan politics, law, economy, culture and the like. One could perhaps even argue that in terms of these latter functions, its visibility as a capital city actually increased following the departure of the court. However, the growing centralization of the Spanish monarchy, especially beginning with the Bourbon ascendancy of the eighteenth century, rendered this notion more vestigial as time went by, as Madrid consolidated its role as the capital that counted, that of the nation-state.

Curiously enough, a number of other European cities underwent much the same experience during the same period. A closer look at these trajectories helps us better to understand trends back in Barcelona. Kraków, for example, had been the capital and court of the Jagellonian dynasty that ruled Poland-Lithuania until the new Vasa king, Sigismund III, named Warsaw the capital in 1609. ${ }^{9}$ The parallel here with the experience of Barcelona is, to be sure, not exact. While both Warsaw and Kraków belonged to the same state, the shift in the centre of political gravity from Barcelona to Madrid involved crossing important political and territorial lines, from one kingdom (the principality of Catalonia within the Crown of Aragon) to another (Castile). Strictly speaking, prior to the eighteenth century Madrid was the 'capital' of Catalonia only to the limited extent that it was the residence of its monarch, which is a fairly incomplete definition of a capital. Barcelona's experience was much closer to that of Prague, especially after it began to lose its place of precedence to Vienna in the later sixteenth century, and definitively after the failed revolt of the Bohemian Estates in 1618. The shift here similarly took place between one kingdom and another, and involved the confusion of capitality with the court. Finally, a third comparison could be cited, that with Dublin. While Dublin had never been formally named the capital of medieval Ireland, the administrative arrangements following the English conquest that culminated in 1603 at no point involved abandonment of capital functions. Throughout the early modern era Dublin served as a viceregal capital, while the court of its sovereign was located in London. The parallel with the experience of pre-1714 Barcelona is a close one, with the important exception of the timing of military conquest. This was missing in Barcelona until 1714 - the siege whose aftermath saw the abolition of traditional Catalan political institutions, including the centuries-old system of municipal self-government - or, at most, 1652, the date of another siege that brought Barcelona back into the Spanish monarchy following its separation under French aegis during the so-called 'War of the Reapers' that began in 1640 .

\footnotetext{
9 The shift actually took a bit longer, as the royal family left Kraków in 1597 after a fire in the Wawel Castle. Warsaw had already been the seat of the Polish Diet since 1569. Details in J. Lileyko, A Companion Guide to the Royal Castle in Warsaw (Warsaw, 1980), 33-4.
} 
Two other comparisons come altogether nearer to the mark. The first is with Naples, the court and governmental centre of a medieval kingdom reduced administratively to a viceroyalty under the Spanish monarchy following the reign of Ferdinand the Catholic. (Here the question of the ruler's status counts for something. Naples as city-kingdom comes closer to the experience of Barcelona-Catalonia-Aragon than does the other Italian candidate, Milan, in that Lombardy was a recently constructed signoria that lacked traditions of kingship when it fell under Spanish control in the early sixteenth century). ${ }^{10}$ Yet clearly the closest parallels involve another ex-capital, Edinburgh. The fit is best for two reasons. The first involves the chronology of institutional change. Edinburgh yielded up its formal status as a capital at virtually the same time Barcelona did, that is, the opening decades of the eighteenth century. Moreover, both had previously experienced loss of a key component of early modern capitality, royal residence. Edinburgh had ceased to house the court beginning in 1603, when James VI moved south to London, roughly a century after Barcelona's king had abandoned it for good. There was, of course, in all this a significant difference involving intention and will. Edinburgh surrendered sovereignty through a voluntary Act of Union (1707). The contrast with Barcelona's final loss of capitality (and much else) following the siege of 1714 could hardly be more dramatic. Still, the overall parallel in timing holds firm.

The other crucial similarity between the history of these two cities is one of, for lack of a better term, self-image. This introduces a second major factor in Barcelona's history calling for comparison, the distinctive focus on what has been called 'civil society' as the most prominent characteristic, or dynamic, in the city's past. The notion of Barcelona - and Edinburgh as cities specially driven by energetic and aspiring 'civil societies' is very closely linked to the notion of capitality and its loss. Civil society here as elsewhere is invariably depicted as the inverse of political power. That is, the concept evokes forms of strength emanating not from high-political decision-making - the dictate of a monarch naming such or such city his court - that is the raison d'être of formal capitals. Rather, it refers to a type of power differing from, if not alien to, politics, the power that derives from the collective efforts of a people in their normal daily lives of productive work and association. Civil society, in other words, tends to be the ideology of economic as opposed to political capitals. Opposition between the two types of urban society and polity is very much at the root of the concept.

It has been suspected even beyond Scotland that the leading role Edinburgh intellectuals played in the articulation of the modern notion of civil society in the realms of political philosophy, jurisprudence,

10 See, for example, G. Galasso, 'Una capitale dell'impero', in his Alla periferia dell'impero. Il regno di Napoli nel periodo spagnolo (secoli XVI-XVII) (Turin, 1994), 335-69. 
historiography and economic thought had much to do with the character of the city itself in the crucial period following the Act of Union. ${ }^{11}$ Edinburgh had long been distinguished as a centre of educational and legal services. It housed not only a university, but also Scotland's civil law courts (the Court of Session, founded in 1532), its criminal courts (the Court of Justiciary), the Privy Council and the Scottish Parliament, as well as the Protestant General Assembly, which met there twice yearly beginning in 1560. Such a notable concentration of gentry, lawyers, professors and clerics prepared the political and social ground for the emergence of the striking constellation of writers, academics and philosophers - Hume, Smith, Millar, Ferguson and, closer to Spanish interests, the historian William Robertson, among others - of the Scottish Enlightenment. It was these distinguished citizens of a cultural, economic, social, legal and administrative capital now rendered a political ex-capital, who refined the notion of civil society as a construct of social and political theory, a stage in historical evolution, and a condition of contemporary urban life. ${ }^{12}$

Anyone familiar with Barcelona's civic discourse will immediately recognize the potency of this notion for the city's self-image. Yet the special, determining presence in Barcelona of a 'civil society' is a myth and here I use this term in the agnostic sense of a tale told to convey a

11 This is the thesis of James Buchan's exuberant Crowded with Genius: The Scottish Enlightenment: Edinburgh's Moment of the Mind (New York, 2003). Some of the highlights in the large and growing bibliography on early modern Edinburgh include: A.J. Youngson, The Making of Classical Edinburgh (Edinburgh, 1966); M. Lynch, Edinburgh and the Reformation (Edinburgh, 1981); R.A. Houston, Social Change in the Age of Enlightenment: Edinburgh, 1660-1760 (Oxford, 1994); H. Dingwall, Late Seventeenth Century Edinburgh (Aldershot, 1994); and S. Nenadic, 'Middle-rank consumers and domestic culture in Edinburgh and Glasgow, 1720-1840', Past and Present, 145 (1994), 122-56. For the city's cultural history in particular, see N. Phillipson, 'Commerce and culture: Edinburgh, Edinburgh University, and the Scottish Enlightenment', in T. Bender (ed.), The University and the City from Medieval Origins to the Present (New York, 1988), 100-18, as well as his earlier overview, 'The Scottish Enlightenment', in R. Porter and M. Teich (eds.), The Enlightenment in National Context (Cambridge, 1981), 19-40. A recent essay with an up-to-date bibliography is M. Geuna, 'Republicanism and commercial society in the Scottish Enlightenment: the case of Adam Ferguson', in M. van Gelderen and Q. Skinner (eds.), Republicanism: A Shared European Heritage, vol. II: The Values of Republicanism in Early Modern Europe (Cambridge, 2002), 177-95. For nineteenth-century Edinburgh, see the detailed study of Richard Rodger, The Transformation of Edinburgh: Land, Property and Trust in the Nineteenth Century (Cambridge, 2001).

12 For an exemplary comparative approach to this question, see J. Robertson, 'The Enlightenment above national context: political economy in eighteenth-century Scotland and Naples', Historical Journal, 40 (1997), 667-98, and now his The Case for the Enlightenment: Scotland and Naples, 1680-1760 (Cambridge, 2005).

The self-image of civil society was perhaps not unrelated to the fact that both cities proved to be bastions of dynastic loyalism in contrast to nearby rural insurgency, respectively in the Highlands in the 1740s and throughout the nineteenth century in regard to Carlism. I raise this point all too briefly in my 'Memoria histórica y tradición cívica: algunas reflexiones sobre el caso de Barcelona en la Edad Moderna', in P. Fernández Albaladejo (ed.), Los Borbones: dinastía y memoria de nación en la España del siglo XVIII (Madrid, 2001), 544-5; the issue obviously merits more detailed examination. 
truth, not a falsehood - that needs a close, hard look..$^{13}$ All too little is known about the emergence of modern middle-class culture in Barcelona, especially its more crucial aspects, such as the relations between urban culture and the sphere of religion, one of the most pronounced lacunae in our knowledge of the city's past. Any such history would have to come to grips with the embarrassing fact that the Enlightenment glistened much less in Barcelona than one would have expected. ${ }^{14}$ Such a fact - which stands out like a sore thumb in any comparison with Edinburgh - clearly requires explanation. One wonders, for example, what responsibility local institutional arrangements might have had for this state of affairs. The recently installed Bourbon government's removal in 1717 of Barcelona's university to the town of Cervera doubtless played a role here, although it would be a mistake to place too much emphasis on this factor, especially given the lacklustre role of this diploma mill in the past. The Enlightenment and, indeed, the secularization process of modernity as a whole was not much in the hands of professors anywhere in Europe. In fact, the first prominent spokesman of the ideology of Barcelona - and Catalonia as paragons of civil society was Antoni de Capmany, a writer and historian not only closely linked to local commercial interests, but also well connected at court. Clearly other factors were at work here, and their identification would doubtless be made easier by systematic comparison with the experience of cities elsewhere.

Once again, it is worth emphasizing that comparison does not always mean searching for, much less finding, similarities. The differences that one runs across can be equally important, and so it is with the comparison between Barcelona and Edinburgh. It is doubtless significant, for example, that Edinburgh and many other ex-capitals - most prominently Naples, but also Kraków and, to a lesser extent, Prague - possessed physical, architectural attributes of capitality famously lacking in Barcelona. ${ }^{15}$

${ }^{13}$ For one critical evaluation of the application of this construct to the study of early modern society, see E. Muir, 'The sources of civil society in Italy', Journal of Interdisciplinary History, 29 (1999), 379-406. For a suggestive comparative overview of the notion of civil society that centres on voluntary associations, see S.-L. Hoffmann, 'Democracy and associations in the long nineteenth century: toward a transnational perspective', Journal of Modern History, 75 (2003), 269-99.

Another Enlightenment concept closely allied to civil society is that of the 'public sphere', on which I will not comment here. Suffice it to note its increasing, and at times rather confused, presence in recent discourse emanating from present-day Barcelona. One example is the official - as in the writings of the local architect and politician Oriol Bohigas presentation of Olympic Barcelona as a showcase of 'neighborhood urban planning'. For a summary, see R. Grau, 'Les opcions de Barcelona, ahir i avui: a propòsit dels ideals urbanitzadors d'Oriol Bohigas', L'Avenç, 257 (2001), 8-13.

${ }^{14}$ Indeed, one recent survey - Thomas Munck's The Enlightenment: A Comparative Social History, 1721-1794 (London, 2000) - has no entry in its index for Barcelona. It is also fair to point out, though, that there is no entry for Spain either, and that southern Europe as a whole is virtually absent from this all too typical study.

15 See J. Robertson, 'Stuart London and the idea of a capital city', Renaissance Studies, 15 (2001), 37-58, for differing views of the architectural and urbanistic requirements of early modern capitality. 
Above all, Edinburgh was more explicitly a centre for services than was Barcelona. The profession of law was particularly prominent in both cities in the sixteenth and especially seventeenth centuries, but beginning in the eighteenth century legal activities began to decline in relative importance in Barcelona, thanks in large measure to the increasingly rapid expansion of local industry. ${ }^{16}$

Which brings us to a third set of comparisons, one that centres around the all-inclusive opposition between 'economic' and 'political' cities. Barcelona's self-image as an economic city is far from inwardly focused. There is in fact, as noted above, something about ex-capitals that makes them insistently attribute their strength to dynamic civil societies instead of the 'mere' presence of government and administrative institutions. The 'mereness' of the latter is the central feature in the consistently negative image citizens of economic capitals project of their triumphant rivals, as in the case of Prague versus Vienna, or Barcelona contra Madrid. ${ }^{17}$ In this mythology capitality is represented less as a function whose loss is to be regretted, than as a demeaning role rejected on grounds of greater urban authenticity. Seen in this light, Barcelona's longstanding character as a commercial and industrial centre endows it with unquestionable superiority in regard to 'artificial', 'parasitic' centres such as state capitals.

This leads to a new tier of comparison, this time between Barcelona and the other 'second cities' of Europe: Lyon in relation to Paris, Milan in the shadow of Rome, Hamburg behind Berlin, and the like. ${ }^{18}$ To be sure, Barcelona took a fairly long time to gain the status (and recognition) of second only to Madrid. For most of the early modern era, Seville (followed by Cádiz), and for a brief moment Lisbon, held second place. Barcelona did not fully take over its role as economic as opposed to political capital of Spain until the nineteenth century. All the same, in this its experience was typical of that of most other European countries, which also saw similar instability within the upper-most positions of the urban hierarchy. Such instability was rooted either in the late definition of political capitals

16 The legal profession would soon recover its earlier protagonism. See Stephen Jacobson's 'Professionalism, corporatism, and Catalanism: the legal profession in nineteenth-century Barcelona' (unpublished Tufts University Ph.D. thesis, 1998), soon to appear in book form.

17 The construction of Prague's self-image in opposition to Vienna is an implicit theme in Peter Demetz's Prague in Black and Gold: Scenes in the Life of a European City (New York, 1997); Lou Rose also pointed it out to me in an as yet unpublished text on Mozart and Vienna. A serious history of the peculiar yet far from unparalleled rivalry between Barcelona and Madrid has yet to be written. Such an exercise in the comparison of different types of capital cities would doubtless reveal much of interest. It may find, for example, that certain forms of classic bourgeois liberalism - such as abolitionism, or defence of free tradewere easier to find in nineteenth-century Madrid than in Barcelona, as Josep M. Fradera has suggested in his Cultura nacional en una sociedad dividida. Cataluña, 1838-1868, trans. C. Mercadal Vidal (Madrid, 2003; orig. edn 1992), 26.

18 One especially useful study in this regard is F. Bartolini, Rivali d'Italia: Roma e Milano dal Settecento a oggi (Rome and Bari, 2006). I regret not having been able to see the obviously comparative work by B.A. Ruble, Second Metropolis: Pragmatic Pluralism in Gilded Age Chicago, Silver Age Moscow, and Meiji Osaka (Cambridge, 2001). 
(Berlin, Rome, Brussels) or in the replacement of one second city by another, as, for example, when in the nineteenth century Liverpool overtook Dublin as the second-ranked city of the United Kingdom. ${ }^{19}$

The focus here is obviously on economic trajectories, and there is much to be learned by contrasting Barcelona's evolution with that of other cities of roughly the same size and complexion. Not all of these were ex-capitals or second cities. Other factors - physical proximity among trading partners, for instance, or the density of commercial relations invite a comparative glance. I have long been convinced that an extremely interesting book could be written about late medieval and early modern Barcelona in relation with its three direct trade rivals: Genoa, Marseille and Valencia. For a slightly later period, comparison with Milan would be quite revealing. The recent emphasis on the substantial resilience of the seventeenth-century Milanese urban economy in its transition from industrial to commercial centre bears a strong resemblance to Albert Garcia Espuche's dramatic revision of Barcelona's economic history during the same era. ${ }^{20}$ (Note also that in both cases urban economic dynamism was buoyed, and indeed made possible, by far-reaching changes in production and distribution in the nearby countryside.) And study of the experience of full industrialization during the nineteenth century could easily go beyond the standard folkloric reference to Barcelona as 'Spain's Manchester' a comparison of more limited utility, perhaps, given the significant differences in the pre-industrial backgrounds of the two cities - to embrace a wide range of contrasting paths, such as those taken by Turin or, for that matter, Frankfurt. ${ }^{21}$

Perhaps the most singular feature of the city's history that these and other economically centred comparisons would reveal would be Barcelona's remarkable record as a comeback city. By this I mean the impressive capacity it has shown on more than one occasion to rise from the troughs in typical cycles of urban expansion and decline. Barcelona is a city of second chances. ${ }^{22}$ These include at least three recoveries: from the

${ }^{19}$ Here I rely on the handy table detailing the population of the 'Leading cities of the European urban hierarchy, $1750-1950$ ', in P.M. Hohenberg and L.H. Lees, The Making of Urban Europe (Cambridge, MA, 1985), 227.

20 See Stefano D'Amico's 'Rebirth of a city: immigration and trade in Milan, 1630-59', Sixteenth Century Journal, 32 (2001), 697-722, as well as his earlier Le contrade e la città: sistema produttivo e spazio urbano a Milano fra Cinque e Seicento (Milan, 1994). Albert Garcia Espuche's Un siglo decisivo: Barcelona y Cataluña, 1550-1640 (Madrid, 1998) has not yet attracted the serious discussion that it merits.

${ }^{21}$ Martin Baumeister of the University of Munich is currently preparing a comparative study of 'urban culture in action' in Barcelona and Turin from the 1860s to the 1930s. I am indebted to Prof. Baumeister for bringing his project to my attention.

22 In this respect, at least, the myth of Barcelona appears as the opposite of the modern nationalist myth of Catalonia: where the latter conceives the past in millenarian terms as a chain of constant defeats, to be reversed in the end by a final victory, Barcelona celebrates its history as a never-ending story of success. For a recent critical assessment of some of the myths of Catalan nationalism, see the other essays in J.M. Fradera and E. Ucelay-Da Cal (eds.), Notícia nova de Catalunya (Barcelona, 2005). 
economic crisis of the later Middle Ages; from the dislocations of the later seventeenth and early eighteenth centuries; and more recently during the ongoing substitution of its aging manufacturing base by a new economy focused on services. ${ }^{23}$ While the latter transition - the economic side of what is now increasingly touted as the 'Barcelona Model' - is actually merely the latest in a series of comebacks in the city's history, it nevertheless differs from its predecessors in the ways the emerging post-industrial city presents itself to the rest of the world. The key ingredients of this 'Model' include a strong emphasis on the city's conciliation of its homegrown historical patrimony of architecture and urban planning with a new and highly dynamic image made up of self-consciously cosmopolitan referents. It is also sustained by an equally strong and self-conscious effort to attract international tourism. Previous efforts in this regard - especially the international expositions that did so much to showcase and promote architectural innovation beginning in the later nineteenth century - were more tentative endeavours, and focused almost exclusively on the city's buoyant architectural present instead of its past.

Needless to say, all this invites comparison, in regard not only to the question of long-term urban resilience, but also to the more general postindustrial turn toward urban culture as a service directed toward both local and non-resident consumers. ${ }^{24}$ Here we run into the single greatest gap in our knowledge of Barcelona's past: the cultural dimensions of its history. Barcelona is a city whose cultural attainments have, until relatively recently, received little more than a nod of the head from the rest of Europe. Why this is, and exactly why its earlier achievements did not attract the attention now accorded to their successors - most notably the architect Antoni Gaudí - are once again matters best revealed by comparison with other cities.

Fortunately, several compelling guides come to our aid. Most notable among them are Carl E. Schorske's broad range of studies

${ }^{23}$ Each of these economic phases has been studied, even if few general conclusions have been drawn from them. Two exceptions to this rule have been the observations in J.K.J. Thomson, A Distinctive Industrialization: Cotton in Barcelona, 1728-1832 (Cambridge, 1992), 312, regarding the unparalleled 'powers of recuperation' of Barcelona's industrial economy, and F. Fernández-Armesto, Barcelona: A Thousand Years of the City's Past (Oxford, 1992), 77, that 'gestures of confidence in response to crisis have been typical of the history of Barcelona and seem, indeed, to constitute a sort of unifying theme that underlies the experience of a thousand years of triumphs and catastrophes'. The latter is a brief but engaging book with more than its share of questionable assumptions, as well as innumerable minor mistakes, but it is undoubtedly the best available general history of the city.

${ }^{24}$ It is perhaps telling that Barcelona is cited only once in Peter Hall's massive Cities in Civilization: Culture, Innovation, and Urban Order (London, 1998), 8, and that is, predictably enough, in regard to its recently forming part of a group of European cities - among them Montpellier, Bologna, Hamburg and Birmingham - that have become more and more preoccupied by the notion that cultural industries (a term no longer thought anomalous or offensive) may provide the basis for economic regeneration'. 
of urban culture, the most recent of which have explicitly turned in a comparative direction. ${ }^{25}$ Other cultural histories that contrast the trajectories of individual cities include the Hungarian historian Péter Hanák's comparison of the capitals of the western and eastern halves of the Austro-Hungarian empire, Vienna and Budapest. ${ }^{26}$ Finally, one can mention an ambitious effort at comparison that directly examines civic culture in a number of cities, including late nineteenth-century Barcelona: Helen Meller's European Cities 1890-1930s: History, Culture and the Built Environment. ${ }^{27}$ And beyond these existing models one can certainly think of a number of promising comparisons involving Barcelona. One especially important one, for example, would be with cities that played a crucial role as centres for the construction and projection of modern nationalism. Such would certainly be the case of Prague. ${ }^{28}$ One could also look at Budapest, Dublin or, once again, Edinburgh in this regard.

It should be clear by this point that I have suggested comparisons with cities that share a minimum of characteristics and conditions with those of Barcelona. While there is, of course, no obstacle a priori to undertaking comparison with utterly dissimilar cases, one nonetheless senses the limited utility of such an exercise. The most valuable comparisons emerge from cities of roughly the same scale, historical depth and complexity of experience. It is by closely matching more or less similar cities that one sees most clearly the telling bumps and notches on one's own.

25 The civic origins and context of cultural creativity have long been a central theme of Schorske's unique brand of cultural history, beginning with his 1963 study of 'The idea of the city in European thought', and continuing through his later essays on Vienna and Basel. The former were published in book form as Fin-de-Siècle Vienna: Politics and Culture (New York, 1980); for the latter, see his 'Science as vocation in Burckhardt's Basel', in Bender (ed.), The University and the City, 198-209. His more recent works have moved in an explicitly comparative direction; see in particular his 'Budapest and New York compared' (co-authored with Thomas Bender), in T. Bender and C.E. Schorske (eds.), Budapest and New York: Studies in Metropolitan Transformation, 1870-1930 (New York, 1993), 1-28, and his introduction to N. Bouvier, G.A. Craig and L. Gossman, Geneva, Zurich, Basel: History, Culture, and National Identity (Princeton, 1994), 1-15, especially 11-12.

26 The Garden and the Workshop: Essays on the Cultural History of Vienna and Budapest (Princeton, 1998). Needless to say, the hackneyed contrast between Budapest, a factory city without green space whose cultural leaders referred to their cafés as workshops, and Vienna, an imperial capital and court given over largely to aristocrats and administrators, seems strongly reminiscent of the Barcelona-Madrid divide. Note, by the way, Hanák's mention of Gaudí (p. 149) as an example of Modernism's having developed earlier in Catalonia, Scandinavia, Italy and Belgium than in Central Europe.

27 (Chichester, 2001). The first chapter (pp. 27-76) contrasts the development of avant-garde art, architecture and urban planning in Barcelona and Munich, both presented as 'second' or 'outsider' cities in respect to their national capitals. For a similar approach in regard to legal culture and its relation to regional and nationalist sentiment, see M. Umbach, 'A tale of second cities: autonomy, culture, and the law in Hamburg and Barcelona in the late nineteenth century', American Historical Review, 110 (2005), 659-92.

28 As along the lines of Scott Spector's Prague Territories: National Conflict and Cultural Innovation in Kafka's Fin de Siècle (Berkeley and Los Angeles, 2000). 


\section{Some future directions}

There are, to be sure, many other questions in regard to Barcelona that would profit from comparative analysis. Four in particular will be briefly mentioned here. First, clearly much more needs to be known about civic elites. The long-term evolution of these groups in Barcelona suggests the existence of a urban variant of the local practice known as pactisme, or ongoing negotiation among political forces and institutions. One particularly suggestive episode took place following the civil wars of the fifteenth century, and wound up ensuring that competition and factional struggles within the elite at no point would get so out of hand as to destabilize the city. In the present, the existing historiography emphasizes a high degree of continuity - as well as a striking absence of internal conflict - beginning in the later Middle Ages and the sixteenth century, which saw the emergence of a consolidated ruling class issuing from the fusion of urban patriciate and traditional gentry of rural origin, and lasting through the incorporation of a larger stratum of 'good families' of industrialist origin in the nineteenth century. ${ }^{29}$ This interpretation - which introduces an Iberian variant to Arno Mayer's well-known thesis regarding the 'persistence of the Old Regime' in modern capitalist societies - has looked above all to the cultural sphere for signs of the interpenetration of old and new generations of elites. ${ }^{30}$ And it is here where the most revealing comparisons - as well as challenges to this interpretation - will doubtless be found. ${ }^{31}$

A second question involves precisely the things that have attracted the most international attention to Barcelona in recent years: architecture and urban planning. In this regard, Barcelona stands out for a number of reasons. Not least among them is the survival of impressive physical traces from all the periods of the city's past. Yet beyond the general interest in Barcelona as a 'historic' city, three moments, or rather movements, in the city's physical fabric lay greatest claim on present-day interest. The first involves Barcelona's boast that it was the birthplace of modern, 'scientific' urban planning in the form of Ildefons Cerdà's mid-nineteenthcentury Eixample, or expansion project located immediately outside the

${ }^{29}$ See above all my Honored Citizens, and G.W. McDonogh, Good Families of Barcelona: A Social History of Power in the Industrial Era (Baltimore, 1986).

30 See A.J. Mayer, The Persistence of the Old Regime: Europe to the Great War (New York, 1981).

31 Thus, for example, Josep M. Fradera, in his 'El huso y la gaita: un esquema sobre cultura y proyectos intelectuales en la Cataluña del siglo XIX', Ayer, 40 (2000), 25-50, broadens the scope of this focus by drawing attention to the significant cultural as well as political divisions within and near this composite elite, in a context of national politics that is virtually absent from both my and McDonogh's studies. As for what happens afterward, the extent to which architects constitute a recognizable cultural-professional group recently incorporated into Barcelona's present-day elite is one of the themes of Llàtzer Moix's $\mathrm{La}$ ciudad de los arquitectos (2nd edn, Barcelona, 2002), although this issue clearly deserves to be explored more fully. 
city centre. ${ }^{32}$ The second hails from the generation immediately after Cerdà, and involves the modernista architecture that enlivened his new city and in which Gaudí played such a spectacularly idiosyncratic role. The final moment has taken place in our times: the architectural and planning initiatives of the past two decades, centring around but not limited to the Olympic Games of 1992 and the so-called Forum of Cultures of 2004. There are innumerable unanswered questions surrounding all three bursts of architectural and artistic activity, to begin with the aging but still unanswered query as to the intellectual, artistic and ideological origins of the two emblematic, even mythical figures of Cerdà and Gaudí. And as for the present-day 'Barcelona Model': for all the hoopla, it clearly enshrines many contradictions and incoherencies - as do, the truth be told, many of the criticisms of it. Comparison with planning practice and the discourse emanating from it elsewhere would do much to clear the air. ${ }^{33}$

An even greater singularity (and one often swept under the rug these days) is that regarding Barcelona's role as the leading centre of urban anarchism in - there is no need to be modest here - world history. It is ironic that a city that garnered such a hard-earned reputation for the acuteness with which it lived out the 'social question' in the nineteenth and early twentieth centuries - Engels referred to Barcelona in 1873 as 'a city whose history has registered more barricade fighting than any other in the world' - has registered so little real progress in historical understanding of its progressive past. All the obvious questions - Why anarchism? Why not socialism? What were its origins? From whence its appeal and its staying power? How did the peculiar local variants of anarchism emerge? What sort of popular culture sustained them? What were the Barcelona left's relations with catalanisme and, for that matter, anti-catalanista sentiments? - not only have not been answered. In many respects, they are still waiting to be posed. ${ }^{34}$ All too often a half-dozen clichés suffice as answers. Many of these moreover hail from a predictably tiresome nationalist mythology that, among other things, identifies the left

${ }^{32}$ For a now-classic statement of this position, see F. Choay, La regle et le modèle: sur la théorie de l'architecture et de l'urbanisme (Paris, 1980), 284-311.

33 Tim Marshall undertakes precisely this sort of analysis in his 'Urban planning and governance: is there a Barcelona Model?', International Planning Studies, 5 (2000), 299-319, a critical appraisal of the 'Model' from the point of view of progressive urban planning.; see also T. Marshall (ed.), Transforming Barcelona: The Renewal of a European Metropolis (London, 2004). For an example of broad disagreement with the 'hegemonic' vision of the Model's defenders based on specific micro-level, neighbourhood concerns, see G.W. McDonogh, 'Discourses of the city: planning and policy in post-transitional Barcelona', City and Society, 5 (June 1991), 40-64, and S. von Heeren, La remodelación de Ciutat Vella. Un análisis crítico del Modelo Barcelona (Barcelona, 2002). For a much more positive reading of the same developments, see N. Calavita and A. Ferrer, 'Behind Barcelona's success story: citizen movements', Journal of Urban History, 26 (2000), 793-807.

34 A promising exception to this rule is G. Barnosell, Orígens del sindicalisme català (Vic, 1999). See also (for a later period) C. Ealham, La lucha por Barcelona: clase, cultura y conflicto, 1898-1937 (Madrid, 2005). 
in general and anarcho-syndicalism in particular with immigration from outside Catalonia. ${ }^{35}$ Sustained attention to working-class historiography elsewhere would help to free local studies from their longstanding obsession with political parties, unions and other formal organizations and to direct attention toward newer and more fruitful venues of research such as popular culture or daily life among the labouring classes.

I trust that there has been enough thrashing about to ensure that no one could mistake where this argument is headed: toward using comparisons to forge a broader and, above all, more broadly cultural approach to Barcelona's past. Much is missing in this city's history. But in the long run it is cultural issues that receive the shortest shrift, and are in most need of analysis. Which brings me to the final set of questions that could in my view most benefit from comparative study: the issue of identities, especially non-institutional solidarities and forms of personal and social identification. ${ }^{36}$ Throughout this essay I have alluded to, without stopping to examine, the symbols, fables, clichés and other building blocks of the collective images that Barcelona, like all cities, generates about itself. Far from being an exception in this regard, Barcelona is a city rich in all sorts of representations. To be sure, it has never developed a firm literary image, to match its (now) better known visual profile. (London has its Dickens, Paris its Balzac, Madrid its Galdós and Barcelona its. . .Narcís Oller?) ${ }^{37}$ The absence of a writer of stature, however, does not mean that Barcelona has ever lacked for civic discourse. On the contrary, it has long been a city engulfed in writing, as well as in a swirl of demotic myths, transmitted in written as well as oral form. Yet despite the evident strength of local myth-making we know all too little about it. ${ }^{38}$ Above all, virtually no effort has been devoted to studying how this highly developed folk mythology links up with the real lives of real people, both as individual citizens and as members of the innumerable circles of adherence and adscription

35 See the historiographic observations in A. Garcia Balañà, 'Sobre "la constitució del proletariat" a la Catalunya cotonera: una crònica de la formació dels llenguatges de classe a peu de fàbrica, $1840-1890^{\prime}$, in Fradera and Ucelay-Da Cal (eds.), Notícia nova de Catalunya, 97-119.

${ }^{36}$ I have briefly drawn attention to this question in 'Institucions no-institucionals? Els fonaments de la identitat social a la Barcelona moderna', in Les institucions catalanes, segles XV-XVII. Actes del Tercer Congrés d'Història Moderna de Catalunya (Barcelona, 1993 [1994]), vol. II, 305-11.

37 Oller (1846-1930) was a well-known novelist whose most famous work, La febre d'or or 'The Gold Rush' (1890-2), dealt with social and economic change in late nineteenth-century Barcelona. For his writing about the city, including his extensive journalistic commentary, see R. Cabré, La Barcelona de Narcís Oller. Realitat $i$ somni de la ciutat (Valls, 2004). For the larger question of Barcelona's literary image, see J. Llovet et al., 'Barcelona en la literatura', Barcelona. Metròpolis Mediterrània, Quadern central no. 20 (n.d.), 65-132, and more recently, C. Carreras, La Barcelona literària. Una introducció geogràfica (Barcelona, 2003).

38 This may be the point to note the special and, frankly, odd role reserved for foreigners as confirmers of local myths from the outside. I am thinking for instance of Robert Hughes' best-selling Barcelona (New York, 1992), or the more modest Homage to Barcelona (London, 1992) by the Irish writer Colm Tóibín. 
that constitute the fabric of urban society. Much can be learned from contrasting these legends, stories and other shards of common sense with those shaping the self-understanding of cities elsewhere. ${ }^{39}$ That little has been done in this regard means, among other things, that the field is wide open, and full of opportunities. ${ }^{40}$

This last sentence is, if nothing else, an argument for optimism. The plan of action I have tried to outline here promises not only to help us rethink the history of Barcelona. It also holds out for the grabbing another opportunity, one in which rethinking Barcelona may contribute in turn to recasting the history of other cities. Comparison is not a one-way street, with all lessons and suggestions heading in the same direction. Taking the problems and possibilities of Barcelona's past to cities elsewhere has something to offer on both ends, and one can only hope that historians of many other urban areas will seize the day.

My bottom hunch is that just as Catalonia breaks with most formal models of national politics, Barcelona departs from much of the standard wisdom regarding urban development. That this is hard to see at times has something to do with the exaggerations and misunderstandings promoted by the hegemonic nationalist historical narrative in present-day Catalonia. The malformations of this historiography may at first sight seem not that relevant to the case of Barcelona. I do sense, however, that some of the gaps in our knowledge of the city's past can be attributed to the strength of nationalist clichés, as well as to the way nationalism's traditional preference for political themes works against the construction of a specifically urban history. The impact of these factors is perhaps most clearly seen in the relative lack of studies on Barcelona in the sixteenth and seventeenth centuries, a period Catalan nationalists have long written off as as an era of 'decadence' lacking in interest. It is only during the past decade that Albert Garcia Espuche - truly a voice crying in the wilderness - has exposed the absurdity of this standard catalanista view

${ }^{39}$ I have in mind studies such as I. Barea [Pollak], Vienna (New York, 1967), or P. Fritzsche, Reading Berlin 1900 (Cambridge, MA, 1996). Other 'urban biographies' focusing on cultural issues include: T.J. Clark, The Painting of Modern Life: Paris in the Age of Manet and his Followers (London, 1984); P.P. Ferguson, Paris as Revolution: Writing the Nineteenth-Century City (Berkeley and Los Angeles, 1994); D.E. Nord, Walking the Victorian Streets: Women, Representation and the City (Ithaca, 1995); B. Ladd, The Ghosts of Berlin: Confronting German History in the Urban Landscape (Chicago, 1998); and K. Clark, Petersburg: Crucible of Cultural Revolution (Cambridge, MA, 1998).

40 One welcome exception is Stéphane Michonneau's recent study, Barcelona: memòria $i$ identitat. Monuments, commemoracions $i$ mites, trans. R. Martínez (Vic, 2002). For a presentation of modern Barcelona's 'civic culture' as a form of political resistance, see T. Kaplan, Red City, Blue Period: Social Movements in Picasso's Barcelona (Berkeley and Los Angeles, 1992). Needless to say, language is another of the more pressing cultural questions calling for a comparative approach. While I know of no historical study of specifically urban linguistic uses, there is ample material on which to build in Joan-Lluís Marfany's La llengua maltractada. El castellà $i$ el català a Catalunya del segle XVI al segle XIX (Barcelona, 2001). 
by demonstrating that it was precisely during this period when Barcelona consolidated its role as economic capital of Catalonia. Even less has been done to challenge another inveterate nationalist cliché: that Barcelona is a 'European' as opposed to a 'Spanish' city, as if it were not both things at the same time. ${ }^{41}$ These and myriad other distortions persist, despite substantial evidence to the contrary. Unfortunately, they wind up shackling Catalan urban history to an anachronistic and impoverished framework that impedes forward movement at popular as well as academic levels of historical understanding.

No history can study only anomalies. Regularities count for much, and any history worth its salt must take them into account. But focusing on peculiarities provides a good starting point for an exploratory analysis that aspires to fill some gaps in the existing narrative. I have tried to suggest that such an approach has much to gain from using the comparative method. It is, simply put, the best means at our disposal to help identify and explore those experiences and conditions that deviate most from general lines of development. Barcelona could easily become one of Europe's leading laboratories for a broad urban history of this sort, thanks to the range and depth of its archival and textual resources. While it is particularly well endowed in three types of sources - notarial and municipal documentation, along with autobiographies, understood in the broad, 'ego-documents' sense of the term - virtually all aspects of the written record of the city's past, both official and non-official, have reached the twenty-first century remarkably intact. ${ }^{42}$ Such a cornucopia of riches invites prospection. Comparison is a sharp and handy tool - sharp and handy enough, in fact, to allow one to do lots of digging.

${ }^{41}$ Felipe Fernández-Armesto is especially insistent on the self-delusion involved in this way of presenting the city's past (and present). See his Barcelona, ix, 197, 203, 207-8 and 231.

42 The most striking exception to this rule involves Barcelona's main parish archives, most of which were destroyed in local disturbances during the nineteenth and twentieth centuries. A vivid idea of the richness of local notarial records may be gleaned from Albert Garcia Espuche's semi-fictional El inventario (Barcelona, 2002). For some preliminary remarks on early modern Catalonia as a centre of autobiographical writing, see my 'The mental world of Jeroni Pujades', in R.L. Kagan and G. Parker (eds.), Spain, Europe and the Atlantic World: Essays in Honour of John H. Elliott (Cambridge, 1995), 211-26, and 'Cataluña desde Europa: las raíces de una cultura autobiográfica', in Catalunya i Europa a l'Edat Moderna: IV Congrés d'Història Moderna de Catalunya (Barcelona, 1998 [2000]), vol. I, 457-62. 